\title{
Daylighting and Readers' Satisfaction: Raja Tun Uda Public Library, Shah Alam
}

\author{
Ahmad Ridzwan Othman ${ }^{*}$, Maz Aiera Mohd Mazli \\ Faculty of Architecture, Planning and Surveying, \\ Universiti Teknologi Mara, Shah Alam, Malaysia \\ dwan_arc7@yahoo.com \\ Tel.: +6-019-2241631
}

\begin{abstract}
Designing library study environment is important to the mood, motivation and performance of individual because interior design plays an important role on human mood and social behaviours. Lighting, as a control architectural tool, gives important influences on users' perception behaviour and visual comfort in libraries. A public library in Shah Alam waschosen as the main subject. The result found that the library users prefer the seat near daylighted area, but the time spend in the library is not really affected by daylighting. Besides for visual comfort, daylighting is not the only contributor to overall comfort and user's satisfaction.
\end{abstract}

Keywords: Daylighting; readers' satisfaction; visual comfort; seating preference

eISSN 2514-751X @ 2018. The Authors. Published for AMER ABRA cE-Bs by e-International Publishing House, Ltd., UK. This is an open access article under the CC BY-NC-ND license (http://creativecommons.org/licenses/bync-nd/4.0/). Peer-review under responsibility of AMER (Association of Malaysian Environment-Behaviour Researchers), ABRA (Association of Behavioural Researchers on Asians) and cE-Bs (Centre for EnvironmentBehaviour Studies), Faculty of Architecture, Planning \& Surveying, Universiti Teknologi MARA, Malaysia.

DOI: https://doi.org/10.21834/aje-bs.v3i7.273 


\subsection{Introduction}

Libraries are important for the student access to permanent information, data sources and documentation records. The design of libraries can enhance or hinder motivation for the student to use them not only during exams, but also in free time. Successful libraries are being planned and used more and more as social gathering places, as well as for deskwork, reading and browsing through books, journals, and digital sources. Designing study environment in a library is important to the mood, motivation and performance of individual because interior design of a room plays an important role on human mood and social behaviour. Lighting, as a control architectural tool, gives important influences on users' perception behaviour and visual comfort in libraries (Hasirci, 2011).

\section{Statement of the Problem}

Most of the designs in building nowadays are lack in the daylighting concept. Daylight is important for the interior space of a building especially to users of the building itself. Building like library is important to have a good daylighting concept for the users' activities and satisfaction.

\section{Purpose and Objective}

The purpose of this study is to investigate the daylight in a library and to determine how the daylight in libraries influences the users' satisfaction.

The objective is:

To know whether daylight affects satisfaction of users in the library.

The main hypotheses are:

Library users prefer the seat near daylighted area, and they will stay longer.

Users are more comfortable at the space in library that has efficient daylighting.

\section{Limitation and Delimitation}

This study is carried out at the main reading area of the library only. It will be done during day time, and on sunny weather condition because it involved daylighting. The artificial lighting cannot be switched off at the reading area during the measurement and observation because it will disturb the function of the library. The lux meter used to measure the illumination levels at each respective desktop surface inclusive of both the daylighting and the artificial lighting values.

\section{Importance of the Study}

The study helps to give an indication of the library users' preferences with regards to daylight availability, hence, provide future designers to design better and efficient seating layout at the reading area. 


\subsection{Literature Review}

\section{Daylighting}

Hasirci (2011) said that daylight influences on user's behaviour and perception because daylight is a control architecture tool. Daylight is one of the features that can increase quality and how long someone will stay in a space. There are three parts of daylight transmitted through windows which are diffuse light, direct transmitted light and redirected transmitted light (Carla Balocco, 2008).

Daylight is variability because as the sun moves, the direction and the amount of daylight enter into the space through the window or roof vary (Dean, 2005). According to Wang and Boubekri (2010), "sunlight produces sensations of pleasantness and warmth, even in an air-conditioned and thermally comfortable room, people are still attracted to sunlight". They found that most of the people chose to sit close to or within the sun patch, although some arranged their desk back to the window and not having a direct outdoor view.

Daylighting is important to school communities in order to improve their performance. One study from Heschong-Mahone Group in 2002 showed that elementary students in the classrooms with the most daylight improve in learning rates compared to students in the classroom with the least daylight by 21 percent.

In the study of Fontoynont (2001), when there is daylight, occupants will prefer lower artificially illuminated levels. For activities that involve computers, occupant preferred light levels of $100-300 \mathrm{~lx}$, while itincreases to $300-600 \mathrm{~lx}$ for occupants that spent less time on computers.

The results of a study by A. Zain-Ahmed et al (2002) have shown that for office spaces in Malaysia, if illuminance falls below $500 \mathrm{~lx}$, the supplementary lighting is required.

\section{Daylight in Library}

The average value for any library activities that involve visual task like reading and writing is about $500 \mathrm{~lx}$, which in a range between 300 and $750 \mathrm{~lx}$ (Carla Balocco, 2008).

Hasirci (2011) found in his research that daylight and outside view are important factors for the satisfaction of the users in the library. The control daylight which is not too bright and glare, satisfied the users of the library which gives comfort to the users. It is preferred to have indirect sunlight in libraries. The sunlight that transmit through a window or skylight bring along light and heat energy to the space (Dean, 2005).

\section{User's Satisfaction}

According to Fontoynont and Escuyer (2001), result on analysis of variance showed that occupant's performance in the reading task and overall efficiency of analogy task are affected by the seating layout. Finding in research at the main library of Dundee University show that the amounts of time spent in a single position in the library have a significant relationship with the users thought that the seat that they choose was designed for maximum use of daylight (Hasirci, 2011). In a study by Cheung and Chung (2008), the main characteristic preferred by the occupants of a residential room is the general brightness and also the desktop brightness 
with an outside view.

Even though, most of the public spaces nowadays are air conditioned, the additional solar heat gain through glass openings somehow influence the indoor set temperature, especially near the perimeter windows. In another study by Lawrence Berkeley Labs, in 2009, the decrease in reading speed and comprehension at $81^{\circ} \mathrm{F}$, compared to $68^{\circ} \mathrm{F}$, was as much as 30 percent. The relative humidity in a space for learning also strongly influences readers' comfort. Readers reported $72^{\circ} \mathrm{F}$ and 60 percent relative humidity quite acceptable. However, as air temperatures rises, the relative humidity should decrease to maintain comfort (Castaldi, 2004).

\subsection{Research Method}

Research approach for this study is quantitative. Perpustakaan Raja Tun Uda, a public library was chosen as a case study. The data analysis was determined from the questionnaires replied from the library users and observation around the library. The questionnaire consists of 2 parts, which is daylighting and visual comfort. The existing measurement instrument, which is rating scale to study the user's satisfaction towards day lighting in library, was use in this study. First of all, the seating layout of the library was drawn and included as one of the instruments to collect data in this study.

\section{Data Collection Procedure}

Questionnaires were given out to the library users to evaluate the importance of each question on 1 to 5 differential scale where "1" meant "strongly disagree" and " 5 " meant "stronglyagree", for the daylighting part. For the visual comfort part, the users were asked to evaluate each question on 1 to 5 also but on the specific situation for each question. Information regarding age, gender, weather condition and time of the day also collected. At the same time, the researcher marked each user's seat preference on the observation sheet which consists of seating layout plan of reading section in the library. The data was collected in the morning, afternoon and evening on the sunny weather condition. Few pictures of the library were taken to provide a visual image and overall mood of the library.

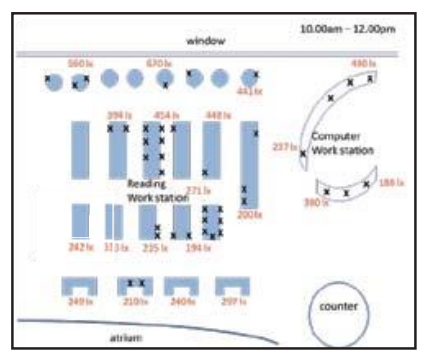

(a)

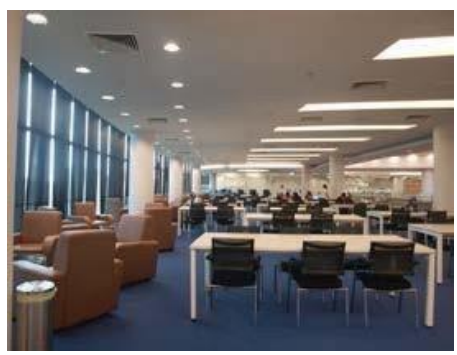

(b)

Figure 1: (a) Location of Position A; (b) The view from Position A 


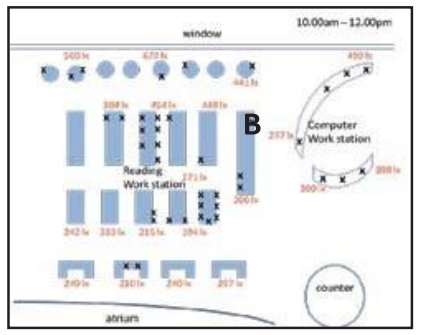

(a)

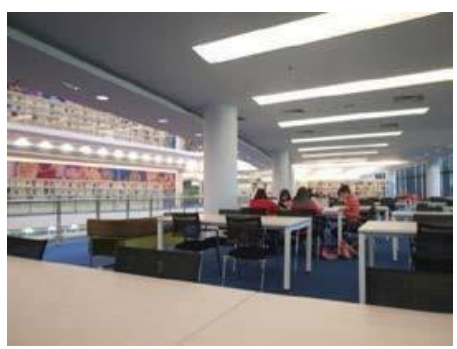

(b)

Figure 2: (a) Location of Position B; (b) The view from Position B

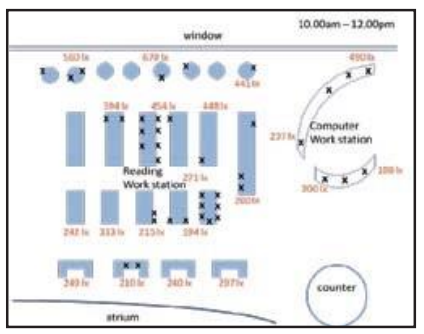

(a)

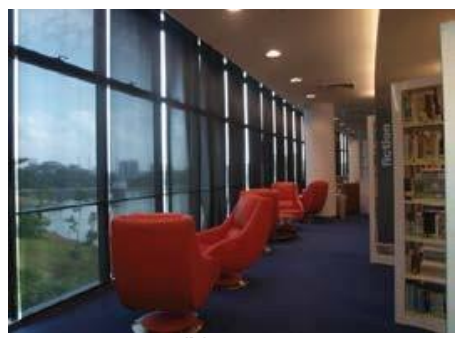

(b)

Figure 3: (a) Location of Position C; (b) The view from Position C

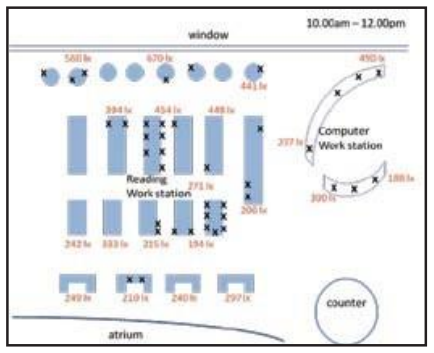

(a)

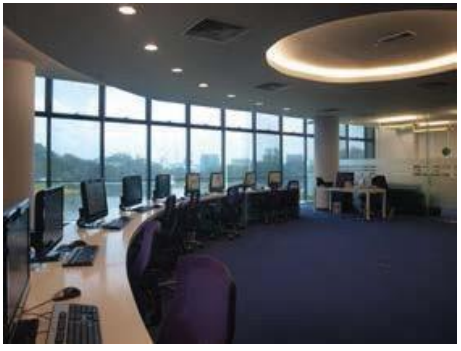

(b)

Figure 4: (a) Location of Position D; (b) The view from Position D

\section{Data Analysis}

The mean of the result will determine whether the daylight at the library affects the seating preferences and the amount of time spent in the library. It will also provide an indication whether the users are satisfied with the level of daylighting which influence the overall visual comfort within the library. 


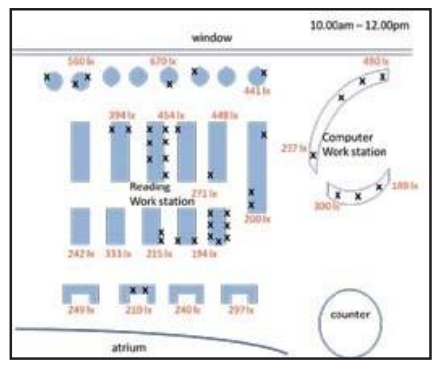

(a)

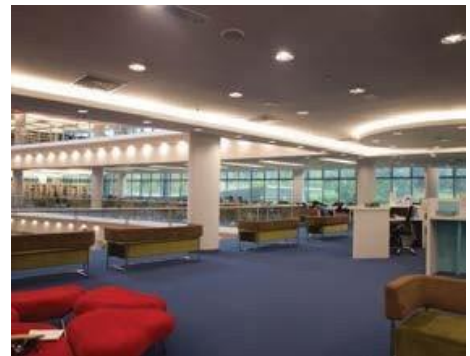

(b)

Figure 5: (a) Location of Position E; (b) The view from Position E

\subsection{Results and Findings}

\section{Observation}

From the observation, user's seating preference in Perpustakaan Raja Tun Uda shows that daylight affected the seating layout of the users in the library. The observation was taken place in three different times in a day, which is from $10.00 \mathrm{am}$ to $12.00 \mathrm{pm}$ (38 respondents), $12.00 \mathrm{pm}$ to $2.00 \mathrm{pm}$ (33 respondents), and $2.00 \mathrm{pm}$ to $4.00 \mathrm{pm}$ (43 respondents). The weather during the observation took place is sunny. The observation shows that the seating preferences were different for the different period of time because of the different amount of daylight at each workspace. The seating preferences and the amount of lighting (in Ix) for each different time of the day are shown in diagrams below (see Fig. 6 - 8).

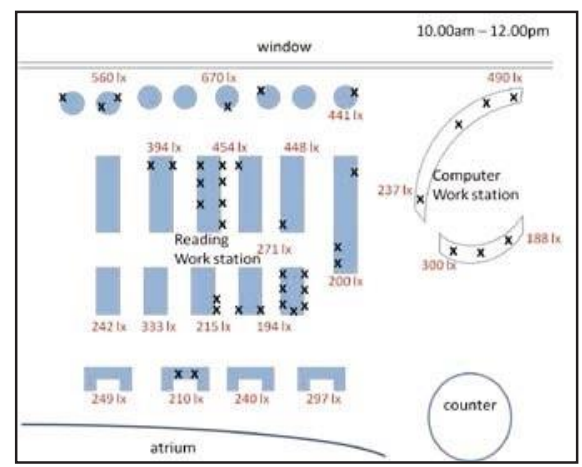

Figure 6: Pattern of Users' Seating Preferences with Lux (illumination) Measurement (10.00 am - $12.00 \mathrm{pm})$ 


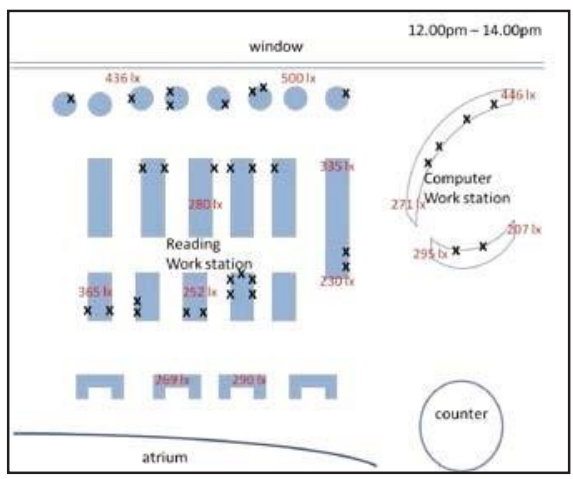

Figure 7: Pattern of Users' Seating Preferences with Lux (illumination) Measurement $(12.00 \mathrm{pm}-2.00 \mathrm{pm})$

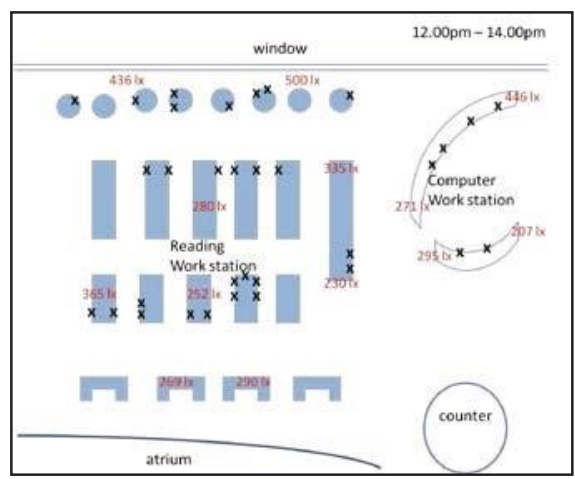

Figure 8: Pattern of users' Seating Preferences with Lux (illumination) Measurement $(2.00 \mathrm{pm}-4.00 \mathrm{pm})$

This shows that there was a significant relationship between the amount of daylight and the seat chosen by the users of the library. From $10.00 \mathrm{am}$ to $12.00 \mathrm{pm}$, users prefer to sit at the centre where the amount of light was between $200 l x-450 l x$, while there were less people sitting near the window where the amount of light was between $560 / x-670 / x$ (Fig. 6). Users prefer to sitnear the window and near the atrium with skylight during $12.00 \mathrm{pm}$ to $2.00 \mathrm{pm}$ where the amount of light was between $250 \mathrm{~lx}-500 \mathrm{~lx}$ (Fig. 7). During $2.00 \mathrm{pm}$ to $4.00 \mathrm{pm}$, users of the library sat randomly where they sat at both at the centre and near the window area, and around the atrium of the library (Fig. 8). The average amount of light throughout the whole workspace was between $230 / x-630 / x$. 


\section{Questionnaires Daylight at the library}

It was found that daylight affects the seating preference of the users.

$42 \%$ agreed that daylight affects their seating preference and $32 \%$ of them strongly agreed with it. Therefore, it was more than half of the respondents $(74 \%)$ agreed that their seating preference affected by the daylight (Fig. 9).

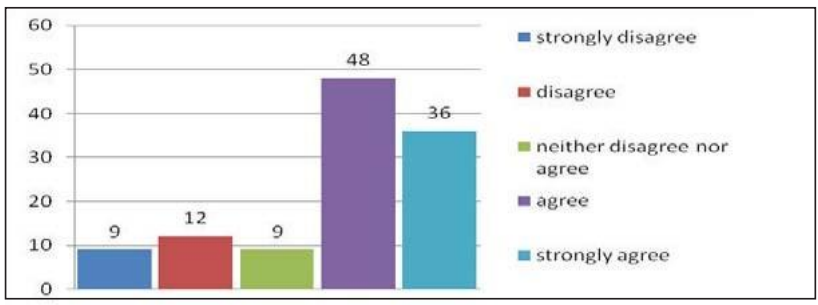

Figure 9: Daylight Affects Seating Preferences (114 respondents)

$32 \%$ of the respondents neither disagree nor agree with the statement that daylight affects the amount of the time spend in the library, while $37 \%$ of the respondent disagree that daylight affects the amount of the time spend in the library. Thus, the amount of time spend in the library was not affected by the daylight (Fig.10).

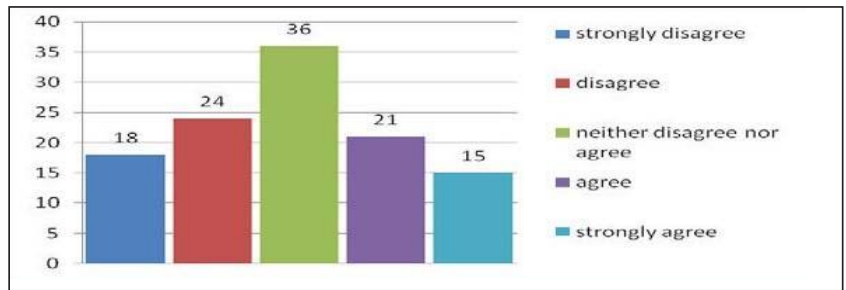

Figure 10: DaylightAffects the Amount of Time Spentin the Library (114 respondents)

For Perpustakaan Raja Tun Uda, about $68 \%$ of them agreed that the design of the seating layout of the library optimizes daylight (Fig. 11).

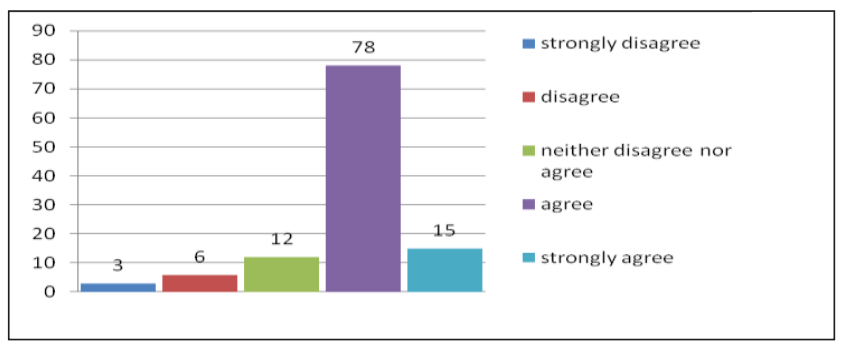

Figure 11: The Design of Seating Layout Optimizes Daylighting (114 respondents) 
$37 \%$ of the respondents agreed that the design of spaces to move around the library optimizes daylight while $34 \%$ of them were neither disagree nor agree with it (Fig. 12).

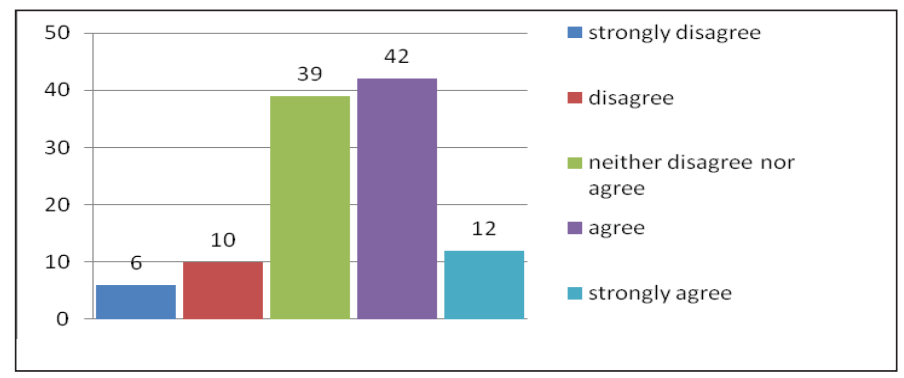

Figure 12: The Design of Spaces to Move around the Library Optimizes Daylighting (114 respondents)

Almost half of the respondents, which is $45 \%$ of them agreed that the arrangement of book shelves in the library optimizes daylight while $39 \%$ of them were neither disagree nor agree with the statement (Fig. 13).

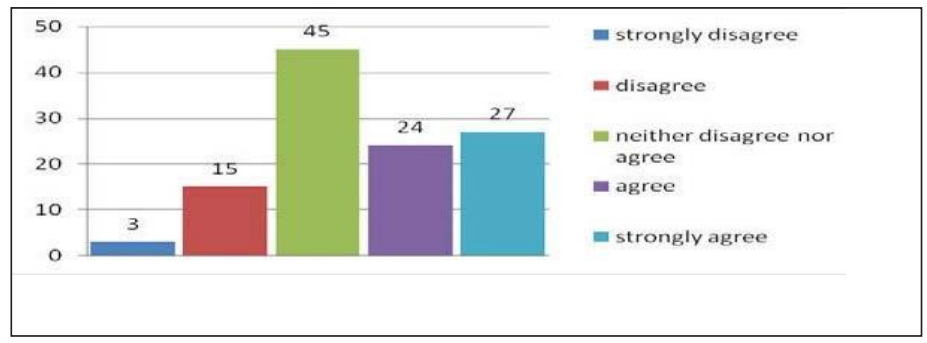

Figure 13: The Arrangement of Book Shelves Optimizes Daylighting (114 respondents)

\section{Users' impression of the space}

The impression and the personal opinion of the users about thework space in Perpustakaan Raja Tun Uda was taken at three different time of a day that is from $10.00 \mathrm{am}$ to $12.00 \mathrm{pm}$, $12.00 \mathrm{pm}$ to $2.00 \mathrm{pm}$ and $2.00 \mathrm{pm}$ to $4.00 \mathrm{pm}$. This is to observe whether different amount of daylight affected the impression and satisfaction of users about the workspace in the library.

In term of pleasantness within the space, the research revealed that the level of respondents' impression increased with time, i.e. averaging from 4.13 (10.00 am - 12.00 pm), to 4.30 (12.00 pm - 2.00 pm), to $4.40(2.00 \mathrm{pm}-4.00 \mathrm{pm})$ (see Fig. 14). 


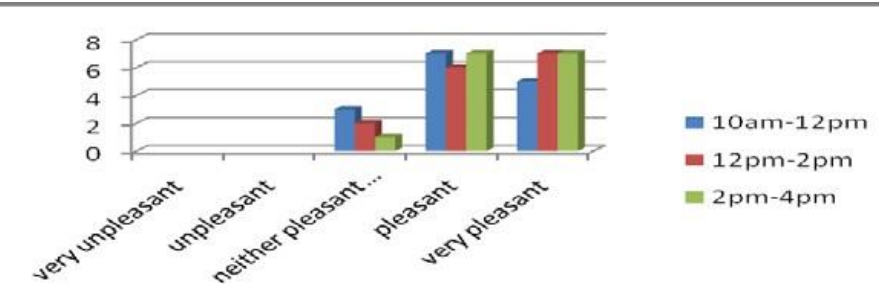

Figure 14: Users' Impression of the Space: Pleasantness

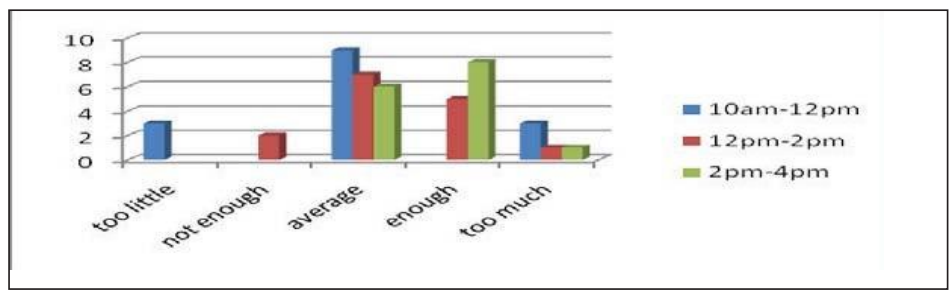

Figure 15: Users' Impression of the Space: Daylight Availability

Respondent's impression with respects to daylighting availability also increased as time moves from $10.00 \mathrm{am}$ to $4.00 \mathrm{pm}$. In the $10.00 \mathrm{am}-12.00 \mathrm{pm}$ period, the respondents' level of impression recorded was 3.00 , in the $12.00 \mathrm{pm}-2.00 \mathrm{pm}$ period it was 3.33 , whilst in the $2.00 \mathrm{pm}-4.00 \mathrm{pm}$ period it was 3.67 (see Fig. 15).

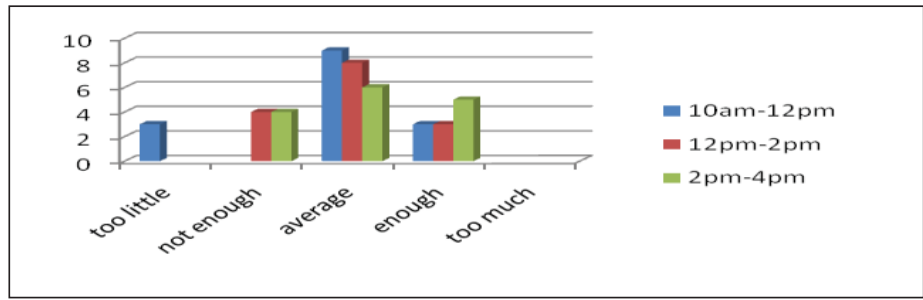

Figure 16: Daylight Availability at the Work Place: Brightness

In the case of daylight availability (brightness), it seems that level of respondent's impression increased with time. In the $10.00 \mathrm{am}-12.00 \mathrm{pm}$ period, the average respondents' level of impression recorded was 2.80 , in the $12.00 \mathrm{pm}-2.00 \mathrm{pm}$ period it was 2.93 , whilst in the $2.00 \mathrm{pm}-4.00 \mathrm{pm}$ period it was 3.07 (see Fig. 16). 


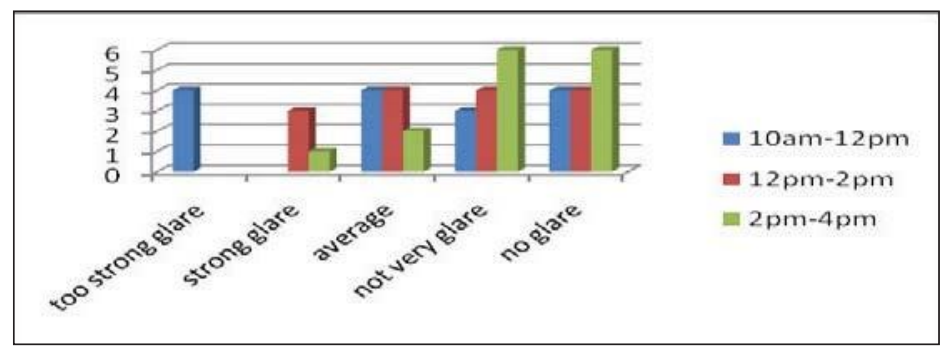

Figure 17: Glare through Windows

Few respondents experienced strong glare, especially those seating close to windows. In the time periods of $10.00 \mathrm{am}-12.00 \mathrm{pm}$ and $12.00 \mathrm{pm}$ to $2.00 \mathrm{pm}$, most of the respondents expressed that the glare level was only average, however, in the $2.00 \mathrm{pm}-4.00 \mathrm{pm}$ time period, most of the respondents claimed that the glare level was not very glare (see Fig. 17).

In summary, between $10.00 \mathrm{am}$ to $12.00 \mathrm{pm}$, most of the library users felt pleasant with the average amount of light in the library, and preferred to seat in the middle, even though there was no strong glare from the window. Between $12.00 \mathrm{pm}$ to $2.00 \mathrm{pm}$, the users preferred to sit near the windows and the atrium because the daylight at that time was very pleasant and completely adequate for writing and reading. While at $2.00 \mathrm{pm}$ until $4.00 \mathrm{pm}$, users sat randomly because there was not enough daylight and they relied on the artificial lighting in the library at that time.

\section{Conclusion}

There was a significant relationship between amount of daylight and the seat chosen by the users of the library. From the questionnaire, more than half of the respondents which was $74 \%$ of them agreed that their seating preference affected by the daylight while, $37 \%$ of the respondent disagreed that daylight affects the amount of the time spent in the library.

It proven the hypothesis 1 , where "library users prefer the seat near daylighted area, and they will stay longer", but the time spent in the library was not really affected by daylighting.

\section{Acknowledgements}

The authors would like to thank Universiti Teknologi MARA and the Faculty of Architecture, Planning and Surveying for the infrastructural and technical support.

\section{References}

A. Zain-Ahmed, Sopian, K., Othman, M.Y.H., Sayigh, A.A.M. \& Surendran, P. N. (2002). "Daylighting as a passive 
solar design strategy in tropical buildings: a case study of Malaysia." Energy Conversion and Management 43: 17251736.

Carla Balocco, R. C. (2008). "Natural light design for an ancient building: A case study." Journal of Cultural Heritage 9: 172-178.

Castaldi, B. (2004). Educational Facilities: Planning, Modernization, and Management. Fourth edition. Boston: Allyn and Bacon.

Cheung, H. D. \& Chung, T. M. (2008). "A study on subjective preference to daylit residential indoor environment using conjoint analysis." Building and Environment 43: 2101-2111.

Dean, E. T. (2005). Daylighting Design in Libraries, Libris Design Project: 3-23.

Fontoynont, M. \& Escuyer, S. (2001). "Lighting controls: a field study of office workers' reactions." Lighting Research and Technology 33(2).

Hasirci, D. K. K. (2011). "Daylighting Concepts for University Libraries and Their Influences on Users' Satisfaction." The Journal of Academic Librarianship 37(6): 471-479.

Heschong-Mahone Group. (2003). Windows and classrooms: A study of student performance and the indoor environment. Technical report P500-03-082-A-7. Fair Oaks, CA: Heschong- Mahone Group.

Lawrence Berkeley National Laboratory. (2009). Temperature and school work performance. Berkeley, CA: Lawrence Berkeley National Laboratory, Retrieved on July 25, 2012, from http://www.iaqscience. lbl.gov/performance-temp-school.html

Wang, N. \& Boubekri, M. (2010). "Design recommendations based on cognitive, mood and preference assessments in a sunlit workspace." Lighting Research and Technology 43(1): 55-72. 